\title{
Introduction to Pragmatism and Common-Sense
}

\section{Gabriele Gava and Roberto Gronda}

\section{(2) OpenEdition}

\section{Journals}

Electronic version

URL: http://journals.openedition.org/ejpap/1034

DOI: 10.4000/ejpap.1034

ISSN: 2036-4091

\section{Publisher}

Associazione Pragma

\section{Electronic reference}

Gabriele Gava and Roberto Gronda, «Introduction to Pragmatism and Common-Sense », European Journal of Pragmatism and American Philosophy [Online], IX-2 | 2017, Online since 22 January 2018, connection on 23 September 2020. URL : http://journals.openedition.org/ejpap/1034 ; DOI : https:// doi.org/10.4000/ejpap.1034

This text was automatically generated on 23 September 2020 .

\section{c)}

Author retains copyright and grants the European Journal of Pragmatism and American Philosophy right of first publication with the work simultaneously licensed under a Creative Commons AttributionNonCommercial-NoDerivatives 4.0 International License. 


\title{
Introduction to Pragmatism and Common-Sense
}

\author{
Gabriele Gava and Roberto Gronda
}

1 The topic of common sense is central to pragmatism, both classical and contemporary. In different ways, Peirce, James and Dewey all wrote extensively on this idea, highlighting its theoretical complexity as well as its heuristic function in philosophical inquiry. In more recent times, to give only one noteworthy example, Nicholas Rescher published a book titled Common Sense (2005) in which he argues against those philosophical approaches that downplay the epistemological importance of common sense and tries to provide "a fundamentally pragmatic construal of the conception of commonsense beliefs" (N. Rescher, Common Sense: A New Look at the Old Philosophical Tradition, Milwaukee, Marquette University Press, 2005, 42). It can well be said, therefore, that common sense represents a pivotal term within the pragmatist tradition in that it intersects with many other key-concepts such as the primacy of practice, contextualism, cognitive pluralism, the implicit knowledge required for action (know-how), the irreducibility of the ordinary world to the descriptions provided by the sciences and pragmatic realism - to name only the most relevant ones.

2 However, pragmatism is far from being the only tradition of thought that has stressed the importance of the notion of common sense for philosophical reflection. As is well known, Thomas Reid and the so-called Scottish school of common sense rejected Locke and Hume's new way of ideas on the basis of the primacy of common sense; similarly, in his 1925 essay A Defence of Common Sense, G. E. Moore formulated a criticism of idealism that starts from the assumption that a certain set of commonsensical beliefs cannot be called into question; in On Certainty, Ludwig Wittgenstein discusses in detail Moore's proposal and uses it as a springboard to formulate his particular version of epistemology, centered around the notion of hinges.

3 A question that is therefore crucial to understanding the pragmatist notion of common sense is whether there is anything specific in the use that the pragmatists have made of this concept. In this respect, one might argue that the classical pragmatists have simply inherited the position of the Scottish school. This approach was widely accepted in the 
United States when Peirce's and James's versions of pragmatism were in their emergent phase and it certainly exerted an important influence on all the classical pragmatists. Yet one might reply that the classical pragmatists did receive the Scottish notion of common Sense critically, introducing relevant changes. Notoriously, Peirce's doctrine of critical common-sensism stems from a critical appropriation of this kind: in his later years, Peirce came to realize that some insights of Reid's philosophy could be accommodated within an 'evolutionist' framework like the one that he was trying to develop. Of course, all this raises a further question regarding the relationship between the pragmatists' notion of common sense and the approach that is distinctive of the Moore-Wittgenstein line. Still another question is whether the pragmatists, classical or otherwise, in fact defend a univocal notion of common sense.

4 Alternatively, one might also ask whether the avowal of common sense principles implies a certain kind of pragmatism even in figures who do not explicitly regard themselves as pragmatists. Put in this form, the question concerning the relationship of pragmatism and common sense is much broader in scope and is not limited to the consideration of the similarities and differences among different philosophical traditions. It is rather a question that goes to the essence of pragmatism itself. For if it is true that endorsing some sort of common sense principles involves the defense of a pragmatist viewpoint, this might point toward an essential feature of pragmatism as such, or at least toward a characteristic which is fundamental to a particular form of pragmatism.

But these are only the 'tip of the iceberg' of a complex set of problems. The aim of this special issue is precisely to investigate this broad subject area by presenting a range of views about the way in which pragmatism is able to understand and conceive of the nature of common sense, its role in human knowledge and its relevance for moral reasoning. The papers contained in this issue address the relationship between pragmatism and common sense both historically and systematically. They assess the historical influences on the pragmatist notion of common sense, in addition to the similarities and differences between the pragmatists and other traditions which have provided central importance to this topic. They also critically consider the conceptual relationships between common sense principles and a pragmatist standpoint on our belief and knowledge. No conclusive and comprehensive view is yet provided. Nor was this our intention. Rather, our task will be achieved if the contributions that make up this special issue foster new discussions on the topic.

\section{AUTHORS}

GABRIELE GAVA

Goethe Universität

gabriele.gava[at]gmail.com 


\section{ROBERTO GRONDA}

Università di Pisa

roberto.gronda[at]unipi.it 